【顎咬合誌, 14(3)：70～73, 1993】

\title{
犬歯誘導とグループ・ファンクションの発現率に関する 実験的解析
}

\author{
保母須弥也* 高山寿夫** \\ Analysis on frequency of occurrence for \\ Canine Guided Occlusion and Group Functioned Occlusion
}

\author{
Sumiya Hobo* Hisao Takayama**
}

The average amount of disocclusion on working side during lateral movement of subjects with normal dentition and free of TMD, was $0.41 \pm 0.27 \mathrm{~mm}$, measured on the study models mounted on a semi-adjustable articulator, using a leaf gauge.

The frequency of occurence for canine guided occlusion (mutually protected occlusion) is larger than that for group functioned occlusion by about 10 times ( 50 samples vs 4 samples).

The fact that there are distinctly significant difference between the average amounts of disocclusion during the protrusive movement and on the nonworking side lateral movement and the one on the working side lateral movement, indicates that the proper amounts of disocclusion is necessary for establishing sound occlusion.

\section{緒 言}

偏心運動時の咬合様式には,バランスド・オクルー ジョン, グループ・ファンクションド・オクルージョ ン，及びミューチュアリー・プロテクテッド・オク ルージョンの3つの態様がある.これらはそれぞれ 側方運動中に，(1) 両側共に兒歯が離開しない場合， (2) 作業側では臼雪が離開せず，非作業側だけ臼歯 が離開する場合, (3) 作業側, 非作業側共に白歯が 離開する場合と言い表わせるので，ここでいう咬合 様式は偏心運動時の臼歯離開の発現態様から見た咬 合夕イプの分類と云ってよいであろう．後 2 者の定 義は次の通りである。1 ミューチュアリー・プロテクテッド・オクルージョン：

咬頭嵌合位では臼歯が前歯を保護し，前方運

*奥羽大学歯学部 **神奈川I科大学, 研究指導部
動では切歯が犬歯と臼歯を保護し, さらに側 方運動では犬歯が切歯と臼歯を保護する咬合 様式. 側方運動中に作業側の犬歯が下顎を誘 導し，その他の歯牙を離開させて為害性のあ る側方圧から保護するため, 犬歯誘導咬合と も呼ばれる。

グループ・ファンクションド・オクルージョン：

側方運動中に作業側の全歯牙が側方圧を分担

し, 非作業側の歯牙を離開させることを特徴 とする咬合様式.

従来, ミューチュアリー・プロテクテッド・オク ルージョンはナソロジーの技法において作り出され る理想的な咬合様式で, グループ・ファンクション ド・オクルージョンは, 天然歯列にしばしば見出さ れる咬合様式であるというのが通説になっている.

しかしその定量的な検討はなされていない。

臼歯離開量を知るために, 保母, 高山²はシリコー ン印象採得材を用い, 正常咬合を有する被験者 16 名 
につき前方及び側方運動時の臼歯離開量の予備的計 測を行なった ${ }^{3}$. その後, 西尾, 宮内, 丸山委保母, 高山の方法に類似した計測方法を用いて側方運動時 の臼歯離開量を計測し, チョッピング・タイプの咀 嚼運動を行なう15名と, グラインディング・タイプ の咀呼運動を行なう10名の被験者群を比較している. しかし, シリコーン印象採得材を用いる計測方法は 細密な測定が可能である反面, 日常臨床の場で歯科 医が正歯離開の定量的診査を行なうには煩雑に過ぎ る難点がある。計測法の選択は被計測量の定義に関 わる一面があるので, 臨床応用を目的とする研究を 行なう場合には, 多少の厳密さを犠牲にしても, 誰 にでも比較的手軽に測定できるような方法を選択す るのが賢明な道というべきであろう，原元，高山， 保母 ${ }^{5}$ は, リーフ・ゲージを用いて臨床的に臼歯離開 量を計測する新しい方法を開発し，前方運動時の臼 歯離開量の計測を行なっている，また星野, 渡辺, 高山, 保母 ${ }^{6}$ は側方運動時の非作業側臼歯離開量を計 測している。

本研究は, 咬合器にマウントした被験者の歯列模 型上で，リーフ・ゲージを用いて側方運動時の作業 側における臼歯離開量を計測し，ミューチュア リー・プロテクテッド・オクルージョンとグループ. ファンクションド・オクルージョンの発現率を比較 することを目的にしている.

\section{方 法}

正常咬合を有し，顎関節に障害のない成人男子 25 名（22 39才, 平均年令26才) の歯列模型を咬合器 上にマウントレ, リーフ・ゲージを用い, 次の方法 で側方運動時の作業側における臼歯離開量を測定し た.

リーフ・ゲージは50枚 1 組でシート 1 枚の厚み 0.1 $\mathrm{mm}$, 幅 $9 \mathrm{~mm}$ のものを用いた。この幅は第 1 及び第 2 大曰歯各 1 本の近遠心径, ならびに第 1 及び第 2 小臼歯を合わせた小田歯 2 本の近遠心径にほぼ等し い.チェックバイトにより咬合器の顆路調節を行 なった後, 右側方運動時には左側, 左側方運動時に は右側の関節部にレジン製のブロックを抻入するこ とにより, 顆頭球の移動量 $3 \mathrm{~mm}$ の側方位に固定し た. 上下顎臼歯咬頭間にリーフ・ゲージを挿入し,
右側方運動時には右側歯列の, 左側方運動時には左 側㐘列の第 1 及び第 2 小曰歯部，第 1 大臼歯，第 2 大臼歯の順に左右計 6 箇所の臼歯離開量を計測した.

リーフ・ゲージを上下顎臼歯咬頭の間に挾み，咬 合器の上顎フレーム上面中央部のマウンティングリ ング固定ネジを片方の手で押しながら，それと“同 じ位の力”を加えて他方の手でリーフ・ゲージを引 き抜いた(図)。咬合器のつまみを押す力が強すぎる

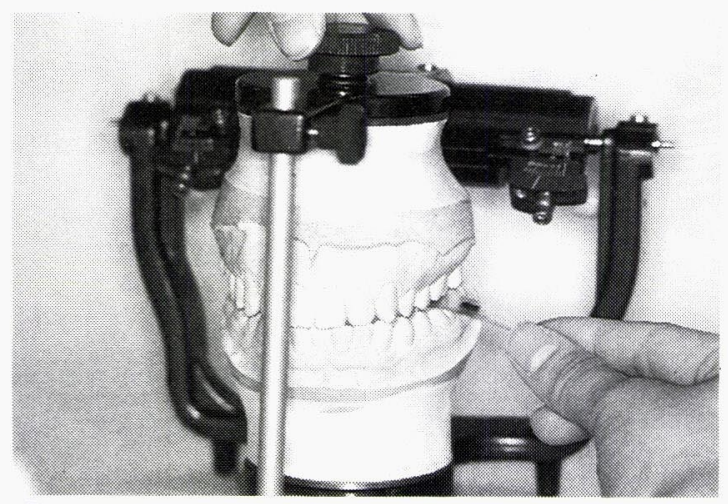

図咬合器の一方の関節にレジン・スペーサを挿入して 3 $\mathrm{mm}$ の側方運動を行なわせ，スペーサを挿入した反对 側（作業側）の上下顎臼歯咬頭の間にリーフゲージを 挾み，上顎フレームを片方の手で押しながら，他方の 手でリーフ・ゲージを引き抜き臼歯離開量を測定した。

と顆頭球が後壁から離れることがあるので（特に第 2 大臼歯測定時), 指で押した際に上顎フレームが前 傾したり,リーフ・ゲージを引き抜くとき強い衝撃 音がしないように注意した。

1 枚のリーフ・ゲージ $(0.1 \mathrm{~mm})$ を引き抜けない ときの離開量を $0.0 \mathrm{~mm}, 1$ 枚なら引き抜けるが 2 枚 重ね $(0.2 \mathrm{~mm})$ にすると引き拔けないときの離開量 を0.1mm, 以下同様とした。

\section{結 果}

計測結果を表 1 に示す。表 1 に示した計測結果か ら次のようなことが分かった。

1) 側方連動時の作業側における田㐘離開量は全臼 歯平均で $0.41 \pm 0.27$ ( S D ) $\mathrm{mm}$ であった。

2 ) 第 1 及び第 2 小田歯部，第 1 大臼歯，第 2 大臼 歯の間で側方運動時の作業側における平均臼歯 離開量を比べると，大きい順に第 1 大臼歯，第 2 大臼歯, 小臼歯部となり, 第 1 大臼歯の臼歯 
表 1 作業側における齿雄開量

(単位：mm)

\begin{tabular}{|c|c|c|c|c|c|c|c|}
\hline $\begin{array}{l}\text { 被験者 } \\
\text { 番号 }\end{array}$ & \multicolumn{3}{|c|}{$\begin{array}{c}\text { 上段：右側方運動·右歯列 } \\
\text { 下段：左側方運動·左歯列 } \\
\mathrm{P}_{12} \cdot \mathbf{M} 1 \cdot \mathbf{M} 2\end{array}$} & $\begin{array}{l}\text { 被験者 } \\
\text { 番号 }\end{array}$ & \multicolumn{3}{|c|}{$\begin{array}{c}\text { 上段：右方運動·右歯列 } \\
\text { 下段：左側方運動·左歯列 } \\
\mathbf{P}_{12} \cdot \mathbf{M} 1 \cdot \mathbf{M} 2\end{array}$} \\
\hline 1 & $\begin{array}{l}0.2 \\
0.5\end{array}$ & $\begin{array}{l}0.6 \\
0.5\end{array}$ & $\begin{array}{l}0.2 \\
0.6\end{array}$ & 14 & $\frac{0.0}{0.4}$ & $\begin{array}{l}0.3 \\
0.6\end{array}$ & $\begin{array}{l}0.5 \\
0.5\end{array}$ \\
\hline 2 & $\frac{0.0}{0.2}$ & $\begin{array}{l}0.2 \\
0.6\end{array}$ & $\begin{array}{l}0.3 \\
0.7\end{array}$ & 15 & $\begin{array}{l}0.7 \\
0.3\end{array}$ & $\begin{array}{l}1.4 \\
1.0\end{array}$ & $\begin{array}{l}1.2 \\
0.9\end{array}$ \\
\hline 3 & $\frac{0.1}{0.7}$ & $\frac{0.1}{0.7}$ & $\frac{0.0}{0.5}$ & 16 & $\underline{0.1}$ & $\frac{0.0}{0.3}$ & $\frac{0.0}{0.2}$ \\
\hline 4 & $\frac{0.1}{0.3}$ & $\begin{array}{l}0.5 \\
0.3\end{array}$ & $\begin{array}{l}0.4 \\
0.3\end{array}$ & 17 & $\frac{0.1}{0.2}$ & $\begin{array}{l}0.3 \\
0.4\end{array}$ & $\frac{0.0}{0.2}$ \\
\hline 5 & $\begin{array}{l}0.3 \\
0.8\end{array}$ & $\begin{array}{l}0.6 \\
0.8\end{array}$ & $\frac{0.0}{0.6}$ & 18 & $\begin{array}{l}0.5 \\
0.7\end{array}$ & $\begin{array}{l}1.0 \\
0.5\end{array}$ & $\begin{array}{l}0.8 \\
0.4\end{array}$ \\
\hline 6 & $\begin{array}{l}0.5 \\
0.3\end{array}$ & $\frac{0.1}{0.5}$ & $\frac{0.1}{0.6}$ & 19 & $\begin{array}{l}0.3 \\
0.8\end{array}$ & $\begin{array}{l}0.5 \\
0.8\end{array}$ & $\begin{array}{l}0.5 \\
0.6\end{array}$ \\
\hline 7 & $\frac{0.0}{0.3}$ & $\frac{0.1}{0.5}$ & $\frac{0.1}{0.6}$ & 20 & $\begin{array}{l}0.2 \\
0.2\end{array}$ & $\begin{array}{l}0.6 \\
0.4\end{array}$ & $\begin{array}{l}1.4 \\
0.5\end{array}$ \\
\hline 8 & $\begin{array}{l}0.5 \\
0.0 \\
\end{array}$ & $\begin{array}{l}0.8 \\
0.2\end{array}$ & $\begin{array}{l}0.6 \\
0.2\end{array}$ & 21 & $\begin{array}{l}0.2 \\
0.6\end{array}$ & $\begin{array}{l}0.5 \\
1.0\end{array}$ & $\begin{array}{l}0.2 \\
0.5\end{array}$ \\
\hline 9 & $\begin{array}{l}0.2 \\
0.5\end{array}$ & $\begin{array}{l}0.4 \\
1.1\end{array}$ & $\begin{array}{l}0.6 \\
1.0\end{array}$ & 22 & $\begin{array}{l}0.4 \\
0.7\end{array}$ & $\begin{array}{l}0.6 \\
0.6\end{array}$ & $\begin{array}{l}0.3 \\
0.5\end{array}$ \\
\hline 10 & $\begin{array}{l}0.2 \\
0.0 \\
\end{array}$ & $\begin{array}{l}0.5 \\
0.5\end{array}$ & $\begin{array}{l}0.2 \\
0.2\end{array}$ & 23 & $\begin{array}{l}0.2 \\
0.7\end{array}$ & $\begin{array}{l}0.2 \\
0.6\end{array}$ & $\begin{array}{l}0.2 \\
0.5\end{array}$ \\
\hline 11 & $\frac{0.1}{0.3}$ & $\frac{0.0}{0.3}$ & $\frac{0.1}{0.3}$ & 24 & $\begin{array}{l}0.2 \\
0.2\end{array}$ & $\begin{array}{l}0.7 \\
0.5\end{array}$ & $\begin{array}{l}0.3 \\
0.4\end{array}$ \\
\hline 12 & $\begin{array}{l}0.2 \\
0.2\end{array}$ & $\begin{array}{l}0.4 \\
0.7\end{array}$ & $\begin{array}{l}0.8 \\
0.3\end{array}$ & 25 & $\begin{array}{l}0.2 \\
0.3\end{array}$ & $\frac{0.1}{0.2}$ & $\frac{0.1}{0.2}$ \\
\hline 13 & $\begin{array}{l}0.7 \\
0.0 \\
\end{array}$ & $\begin{array}{l}0.8 \\
0.3\end{array}$ & $\begin{array}{l}0.9 \\
0.2\end{array}$ & $\begin{array}{l}\text { 平均值 } \\
\mathrm{S} \text { D }\end{array}$ & $\begin{array}{l}0.30 \\
0.23\end{array}$ & $\begin{array}{l}0.51 \\
0.30\end{array}$ & $\begin{array}{l}0.43 \\
0.29\end{array}$ \\
\hline & & $\begin{array}{l}\text { 全臼㐘 } \\
\text { 平 块 }\end{array}$ & & $\begin{array}{c}\text { 值 } \\
\text { D }\end{array}$ & & & \\
\hline
\end{tabular}

使用リーフ・ゲージ：3M社製使用咬合器：パナホビー半調篩性咬合器

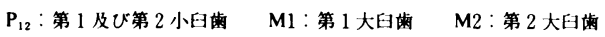

レジン・スペーサ使用……側方顆路長（非作業側）： $3 \mathrm{~mm}$

注）アンターラインは上下顜接触雷牙を示す。

離開量が小臼歯部や第 2 大臼歯より大きい傾向 にあった。

3 ）既報の結果に本研究結果を加えると, リーフ・ ゲージを用いて前方運動時及び側方運動の非作 業側と作業側における臼霜離開量を計測した結 果は, 全臼歯部平均でそれぞれ $1.06 \mathrm{~mm}^{5}, 1.10$ $\mathrm{mm}^{6}, 0.41 \mathrm{~mm}$ (上記本研究結果) となり, 保母 と高山年がシリコーン印象材を用いて予備的に 計測した平均臼歯離開量（それぞれ1.06mm, $1.00 \mathrm{~mm}, 0.47 \mathrm{~mm})$ と近似した結果が得られ た。

4 ）側方運動の作業側において，臼歯離開量が 0.1 $\mathrm{mm}$ 以下の歯牙（表 1 中にアンダーラインで示 す）のある歯列の数は，片側歯列 50 例中15例で, jち小臼歯, 第 1 大臼歯, 第 2 大臼歯の内 1 者 だけが $0.1 \mathrm{~mm}$ 以下なのは 8 例 $(16 \%) ， 2$ 者が $0.1 \mathrm{~mm}$ 以下なのは 3 例 ( $6 \%$ ) で，3 者とも 0.1 $\mathrm{mm}$ 以下なのは 4 例（ $8 \% ） に$ 過ぎなかった。

\section{考 突}

上述のように，著者らが咬合器に装着した成人 25 名の歯列模型上で, リーフ・ゲージを用いて臼歯離 開量を計測した際の被験者別デー夕（表）によると， 側方運動時の作業側において，臼歯離開量が $0.1 \mathrm{~mm}$ 以下の歯牙が 1 本でもある歯列の数は，片側歯列 50 例中15例 $(30 \%)$ で，そのうち小臼歯部，第 1 大臼 歯, 第 2 大臼歯の 3 者とも $0.1 \mathrm{~mm}$ 以下なのは 4 例 （8％）であった。この 4 例は定義通りのグループ. ファンクションド・オクルージョンであるが, この 結果は，厳密な定義通りのグループ・ファンクショ ンド・オクルージョンの発現率は天然歯列中 $8 \%$ に 過ぎず，残りは犬霜誘導咬合（ミューチュアリー・ プロテクテッド・オクルージョン）であることを示 している. 従来グループ・ファンクションド・オク ルージョンは天然歯列内にしばしば見出される咬合 様式とされてきた．上記の結果は従来の通説に反す るもので, むしろ犬歯誘導咬合の方が天然歯列内に しばしば見出される咬合様式であることを示してい る.このように通説が事実と相違する結果になった のは, 従来の咬合様式の定義が定量的でなく, 臨床 の場で単に術者の頓側からの視覚による観測だけで 咬合様式の判別が行なわれていたため, $0.2 \sim 0.3$ $\mathrm{mm}$ 程度の臼歯離開があっても上下顎歯が接触して いるものと判定される傾向があったのではないかと 考えられる。厳密な定義通りにグループ・ファンク ションド・オクルージョンを判定するのが必ずしも 適切とは思わないし，咬合様式の定義も計測法を含 めて見直す必要があると思われるが，いっぱんに咬 合様式と咀嚼運動ないしは咀哷効率などとの関連性 
表 2 天然歯における犬歯誘㬝咬合とグループ・ ファンクションド・オクルージョンの発現率

(最小臼歯離開量 $=0.1 \mathrm{~mm}$ )

\begin{tabular}{|c|c|}
\hline 犬 歯 誘 導 & グループ・ファンクション \\
\hline $92 \%$ & $8 \%$ \\
\hline
\end{tabular}

を検索するような際には，何らかの臼歯離開量計測 を併用するのが望ましいであろう，表 2 に厳密な定 義にもとづいた，天然歯における犬歯誘導咬合とグ ループ・ファンクションド・オクルージョンの発現 率を比較して示す.

第 2 報ではスタディモデルから前歯を撤去した状 態で作業側における田歯離開を計測し, 上述の結果 と比較することとする。

\section{結 論}

正常咬合者の偏心運動時の作業側における臼歯離 開量は, 全臼歯平均で $0.41 \pm 0.27$ (S D) mm であっ た。

作業側の全臼歯が偏心運動時に接触するグルー プ・ファンクションド・オクルージョンの咬合様式 よりも，作業側の全臼歯が離開する犬歯誘導咬合 (ミューチュアリー・プロテクテッド・オクルージョ ン）の咬合様式の方が発現頻度が約 10 倍（4例対 50 例) 高い.

前方運動及び側方運動の非作業側の平均臼歯離開 量と作業側のそれとの間に顕著に有意な相違が見ら れることは, 偏心運動時に上下顎歯牙が僅かでも離 れていればよいというものではなく，健全な咬合状 態を確保するためには適量の臼歯離開が必要なこと を示唆する法則性のひとつと云える。

\section{考考献}

1 ）保母須弥也編：咬合学事典. 書林, 東京, 1977.

2 ) 保母須弥也, 高山寿夫 : ディスクルージョン量 の予備的計測結果とその解析. 補緅誌 29 : 235-236, 1985.

3 ）保母須弥也, 高山寿夫：自歯離開量の予備的計
測. 顎咬合誌 $14 ： 1-3,1993$.

4 ）西尾公一, 宮内修平, 丸山剛郎：咀緭運動に関 する臨床的研究. 補緅誌 $30 ： 806-816,1986$.

5 ）原元信貴, 高山寿夫, 保母須弥也：前方運動に おける臼歯離開量の計測，第 1 報 前歯「有り」 の場合. 顎咬合誌 $14: 4-6,1993$.

6 ）星野 元, 渡辺和夫, 高山寿夫, 保母須弥也： 非作業側における臼歯離開量の計測 第 1 報 犬歯「有り」の場合. 顎咬合誌 $14: 41-44$, 1993.

別刷請求先：高山寿夫

神奈川工科大学

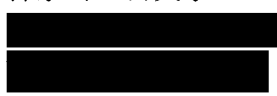

